CURRENT

Jurnal Kajian Akuntansi dan Bisnis Terkini

https://current.ejournal.unri.ac.id

\title{
PENGARUH INTELLECTUAL CAPITAL, LEVERAGE, PROFITABILITAS, DAN LIKUIDITAS TERHADAP NILAI PERUSAHAAN
}

\author{
Azlin Shakila Putri ${ }^{1}$, Desrir Miftah ${ }^{2 *}$ \\ ${ }^{1,2}$ Program Studi Akuntansi, Fakultas Ekonomi dan Ilmu Sosial, Universitas Islam Negeri \\ Sultan Syarif Kasim Riau, Kota Pekanbaru \\ *E-mail: desrir.miftah@uin-suska.ac.id
}

\begin{tabular}{l} 
Keywords \\
\hline Nilai Perusahaan, \\
Intellectual Capital, \\
Leverage, \\
Profitabilitas, \\
Likuiditas
\end{tabular}

\section{Article informations}

Received:

2020-12-03

Accepted:

2021-07-23

Available Online:

2021-07-31

\begin{abstract}
The objective of this study is to analyze the influence of intellectual capital, leverage, profitability and liquidity on firm value. Firm value is measured by price to book value $(P B V)$, leverage is measured by debt to equity ratio (DER), profitability by return on equity (ROE) and liquidity by current ratio $(C R)$. This research method is a quantitative research with sampling using a purpose sampling technique based on predetermined characteristics as many as 9 pharmaceutical sub-sector companies listed on the Indonesia Stock Exchange for the period 2016-2019. The type of data used is secondary data and the analytical method used is panel data regression using Eviews. The results show that intellectual capital, leverage, profitability have a significant effect on firm value. However, liquidity has no effect on firm value. The contribution of this research is that in addition to financial performance, companies need to pay attention to intellectual capital to increase firm value.
\end{abstract}

\section{PENDAHULUAN}

Tujuan Perusahaan adalah memaksimalkan kekayaan atau nilai perusahaan bagi para pemegang saham. Nilai perusahaan yang go public tercermin pada harga pasar saham perusahaan (Wijaya, 2017). Perusahaan dikatakan berhasil mengelola usahanya, jika harga sahamnya terus mengalami peningkatan. Perusahaan harus dapat secara konsisten meningkatkan nilai perusahaan, berarti perusahaan dinilai menarik oleh investor sehingga dapat menarik investor untuk berinvestasi pada perusahaan tersebut.

Nilai perusahaan tercermin dari harga saham yang terbentuk dari investasi yang dilakukan oleh investor. Fenomena yang menjadi dasar penelitian ini terkait harga saham pada perusahaan sub sektor Farmasi di Bursa Efek Indonesia cukup menarik. Tahun 2018 beberapa perusahaan farmasi mengalami penurunan harga saham akibat dari pelemahan nilai rupiah yang berdampak dilepasnya saham-saham farmasi (saham PT Kalbe Farma (KLBF), 
Merck (MERK), dan PT Indofarma (INAF)). Tahun 2019 terdapat dua saham farmasi yang mengalami penurunan kumulatif yakni PT Kimia Farma (KAEF) dan PT Indofarma (INAF). Namun pada penutupan bursa pada tanggal 2 Desember 2019 meskipun Perusahaan INAF mengalami penurunan harga saham tetapi rata rata aktivitas transaksi mengalami peningkatan. Dan pada tahun 2020, setelah Presiden Joko Widodo mengungkapkan terdapat dua orang Indonesia terinfeksi virus corona (COVID-19). Sebanyak empat saham farmasi di Bursa Efek Indonesia (BEI) mendadak menguat jelang penutupan perdagangan sesi II. Namun juga terdapat beberapa saham emiten farmasi yang anjlok di antaranya PT Phapros (PEHA), PT Industri Jamu dan Farmasi Sido Muncul (SIDO) dan PT Kalbe Farma (KLBF) mengalami stagnan (02 Maret 2020, Jakarta, CNBC Indonesia).

Fenomena diatas menunjukkan sangat berfluktuasi harga saham pada kelompok subsektor Farmasi sehingga memicu dilakukannya penelitian ini. Harga saham akan mencerminkan nilai perusahaan, semakin tinggi harga saham maka semakin tinggi pula nilai perusahaan begitupun sebaliknya (Febriana, dkk., 2016). Berdasarkan hasil penelitian terdahulu terdapat beberapa variabel yang mempengaruhi nilai perusahaan, antara lain intellectual capital (IC), leverage, profitabilitas, dan likuiditas.

Intelectual capital termasuk dalam salah satu sumber daya tak berwujud (intangible asset) yang dimaksud dalam Resource Based Theory (RBT). RBT menjelaskan bahwa kinerja perusahaan akan optimal jika perusahaan memiliki keunggulan kompetitif sehingga bisa menghasilkan nilai bagi perusahaan. Keberadaan IC memungkinkan perusahaan menciptakan nilai tambah untuk meningkatkan kinerja perusahaan, Jika kinerja perusahaan meningkat maka pasar akan memberikan respon berupa meningkatnya nilai perusahaan. Ulum (2013) menjelaskan bahwa intellectual capital adalah seluruh sumber daya manusia, pengetahuan dan teknologi yang berada didalam perusahaan yang nantinya dapat membentuk perusahaan tersebut untuk bersaing di pasar saham. Nilai suatu perusahaan dapat tercermin dari harga yang dibayar investor atas sahamnya di pasar. Penelitian yang dilakukan oleh Chandra dan Djajadikerta (2017), Juwita dan Angela (2016) yang menjelaskan bahwa intellectual capital memiliki pengaruh signifikan dan positif terhadap nilai perusahaan. Namun Faza dan Hidayah (2014) dari hasil penelitiannya menyatakan bahwa intellectual capital tidak berpengaruh terhadap nilai perusahaan.

Nilai perusahaan dapat pula dipengaruhi oleh leverage. Semakin besar leverage berarti semakin besar kekayaan perusahaan yang dibiayai melalui utang yang dapat diukur melalui rasio Debt to Equity (DER). Leverage menjadi penting bagi investor dalam membuat keputusan investasi karena dapat mempengaruhi kemampuan perusahaan untuk memberikan pengembalian kepada pemegang saham. Perusahaan yang dapat mengelola leverage dengan baik dapat meningkatkan 
kepercayaan investor sehingga dapat meningkatkan nilai perusahaan. Peningkatan hutang dipandang positif oleh investor sebagai meningkatnya kesempatan perusahaan untuk berkembang sehingga investor berkesempatan untuk mendapatkan pengembalian investasi yang lebih tinggi tanpa harus mengurangi proporsi kepemilikan investor terhadap perusahaan. Hal ini berarti perusahaan yang berhutang mempunyai nilai perusahaan yang tinggi. Peningkatan hutang diartikan oleh pihak luar sebagai kemampuan perusahaan untuk membayar kewajiban di masa yang akan datang atau adanya risiko bisnis yang rendah yang akan direspon secara positif oleh pasar. Penelitian terdahulu yang dilakukan oleh Prastika (2012) dan Nurminda (2017) yang menjelaskan bahwa leverage berpengaruh terhadap nilai perusahaan. Sedangkan penelitian Novari dan Lestari (2016) yang menjelaskan bahwa leverage tidak berpengaruh terhadap nilai perusahaan.

Nilai perusahaan dapat pula dipengaruhi oleh profitabilitas yang dihasilkan oleh perusahaan. Secara teoritis semakin tinggi tingkat profitabilitas yang dicapai perusahaan maka semakin tinggi nilai suatu perusahaan. Profitabilitas adalah kemampuan setiap perusahaan dalam menghasilkan suatu laba berdasarkan dengan total asset yang dimiliki (Hanafi, 2016, p. 81). Profitabilitas ini berpengaruh terhadap nilai perusahaan karena dapat dikatakan apabila laba yang dihasilkan perusahaan ini meningkat maka dapat meningkatkan harga saham di perusahaan dengan meningkatnya harga saham ini menjadikan daya tarik bagi investor untuk menanamkan sahamnya di perusahaan tersebut. Penelitian terdahulu Novari dan Lestari (2016), Dewi dan Badjra (2017) menjelaskkan bahwa profitabilitas memiliki pengaruh positif terhadap nilai perusahaan. Sedangkan hasil penelitian Khumairoh, dkk (2016) dan Moniaga (2013) yang menjelaskan bahwa profitabilitas tidak memiliki pengaruh terhadap nilai perusahaan.

Rasio likuiditas adalah rasio yang menunjukkan perusahaan dapat melunasi tepat waktu kewajiban keuangan yang berjangka pendek. Tingginya likuiditas menunjukkan perusahaan dapat menurunkan dampak yang diakibatkan oleh kewajiban keuangan jangka pendek, dan sebaliknya. Tinggi rendahnya rasio ini akan mempengaruhi persepsi investor terhadap perusahaan jika memiliki nilai likuiditas tinggi yang menunjukkan kinerja perusahaan baik, sehingga akan meningkatkan harga saham yang mencerminkan nilai perusahaan. Likuiditas dalam teori berhubungan positif dengan nilai perusahaan. Penelitian terdahulu oleh Oktaviarni, dkk (2019) menjelaskan bahwa likuiditas berpengaruh positif signifikan terhadap nilai perusahaan. Namun penelitian Lubis, dkk (2017) yang menjelaskan bahwa likuiditas berpengaruh positif tidak signifikan terhadap nilai perusahaan.

Berdasarkan fenomena, teori dan perbedaan hasil penelitian yang telah disampaikan diatas maka penelitian ini dilakukan untuk menguji kembali pengaruh intellectual capital, 
leverage, profitablitas dan likuiditas terhadap nilai perusahaan pada perusahaan sub-sektor Farmasi yang terdaftar di Bursa Efek Indonesia periode tahun 2016 - 2019. Penelitian ini menguji secara keseluruhan pengaruh dari faktor kinerja keuangan perusahaan dan menambahkan variabel intellectual capital yang merupakan salah satu intangible asset bagi perusahaan.

\section{PENGEMBANGAN HIPOTESIS}

\section{Pengaruh Intellectual Capital Terhadap Nilai Perusahaan}

Intellectual capital merupakan kemampuan dan keterampilan berupa pengetahuan yang berguna bagi perusahaan sebagai suatu keunggulan kompetitif sehingga dapat meningkatkan daya saing perusahaan dan ketahanan perusahaan dipasar. Berdasarkan resouces based theory agar dapat bersaing organisasi membutuhkan dua hal utama. Pertama, memiliki keunggulan dalam sumber daya yang dimilikinya, baik berupa aset yang berwujud (tangibleassets) maupun yang tidak berwujud (intangible assets). Kedua, adalah kemampuan dalam mengelola sumber daya yang dimilikinya tersebut secara efektif. Kombinasi dari aset dan kemampuan akan menciptakan kompetensi yang khas dari sebuah perusahaan, sehingga mampu memiliki keunggulan kompetitif di banding para pesaingnya. Sumber daya intelektual merupakan salah satu sumberdaya yang dinilai penting dan memiliki peran dalam menciptakan keunggulan kompetitif. Atas dasar keunggulan kompetitif dan nilai tambah tersebut maka investor yang merupakan stakeholder akan memberikan penghargaan lebih kepada perusahaan dengan berinvestasi lebih tinggi.

Penelitian Santiani (2018), Juwita dan Angela (2016) menunjukkan bahwa intellectual capital berpengaruh positif terhadap nilai perusahaan. Atas dasar teori dan diperkuat penelitian terdahulu, maka hipotesis pertama adalah:

\section{H1: Intellectual Capital Berpengaruh Positif Terhadap Nilai Perusahaan.}

\section{Pengaruh Leverage Terhadap Nilai Perusahaan}

Leverage menunjukkan kemampuan perusahaan dalam memenuhi kewajiban baik jangka pendek dan jangka panjangnya. Leverage dapat dipahami sebagai penaksir dari risiko yang melekat pada suatu perusahaan. Artinya leverage yang semakin besar menunjukkan resiko investasi yang semakin besar pula. Sehingga leverage perlu di kelola karena penggunaan hutang yang baik juga akan meningkatkan nilai perusahaan. Leverage merupakan kemampuan perusahaan untuk menggunakan aktiva atau dana yang mempunyai beban tetap (fixed cost asset or fund) yang gunanya untuk memperbesar tingkat penghasilan (return) bagi 
pemilik perusahaan. Peningkatan hutang dipandang positif oleh investor sebagai meningkatnya kesempatan perusahaan untuk berkembang sehingga investor berkesempatan untuk mendapatkan pengembalian investasi yang lebih tinggi tanpa harus mengurangi proporsi kepemilikan investor terhadap perusahaan. Hal ini berarti perusahaan yang berhutang mempunyai nilai perusahaan yang tinggi. Peningkatan hutang diartikan oleh pihak luar sebagai kemampuan perusahaan untuk membayar kewajiban di masa akan datang yang akan direspon secara positif oleh pasar

Leverage menurut penelitian yang dilakukan oleh Suffah dan Riduwan (2016), menyatakan bahwa leverage berpengaruh positif signifikan terhadap nilai perusahaan. Pernyataan tersebut juga didukung oleh beberapa penelitian seperti Pratama dan Wiksuana (2016) serta Sari dan Handayani (2016) yang menyatakan bahwa leverage berpengaruh positif signifikan terhadap nilai perusahaan. Atas dasar penelitian terdahulu dan diperkuat dengan teori yang ada, maka hipotesis kedua adalah:

\section{$\mathrm{H}_{2}$ : Leverage Berpengaruh Positif Terhadap Nilai Perusahaan.}

\section{Pengaruh Profitabilitas Terhadap Nilai Perusahaan}

Rasio profitabilitas merupakan rasio yang bertujuan untuk mengetahui kemampuan perusahaan dalam mengahasilkan laba selama periode tertentu. Selain itu, juga memberikan gambaran tentang tingkat efektivitas manajemen dalam melaksanakan kegiatan operasinya. Rasio profitabilitas dapat menggambarkan kemampuan perusahaan dalam mendapatkan laba melalui semua kemampuan dan sumber yang ada seperti kegiatan penjualan, kas, modal, jumlah karyawan, jumlah cabang dan sebagainya. Signaling theory menggambarkan bagaimana profitabilitas berpengaruh terhadap nilai perusahaan sehingga dapat dikatakan apabila laba yang dihasilkan perusahaan ini meningkat maka dapat meningkatkan harga saham di perusahaan. Peningkatan harga saham ini menjadikan daya tarik bagi investor untuk menanamkan sahamnya di perusahaan. Hal ini dapat menjadikan adanya hubungan positif antara harga saham dengan profitabilitas, semakin tinggi harga saham maka akan mempengaruhi nilai perusahaan karena nilai perusahaan tercermin dari harga sahamnya. Meningkatnya laba yang dihasilkan oleh perusahaan dapat menjadikan sinyal positif bagi para investor untuk menanamkan sahamnya di perusahaan tersebut.

Berdasarkan penelitian Novari dan Lestari (2016) menyatakan bahwa profitabilitas berpengaruh positif dan signifikan terhadap nilai perusahaan. Didukung oleh penelitian Oktaviarni, dkk (2019), Dewi dan Badjara (2017), Lubis, dkk (2017) yang menyatakan bahwa profitabilitas berpengaruh positif terhadap nilai perusahaan. Berdasarkan hasil penelitian terdahulu dan teori yang ada maka hipotesis ketiga adalah: 


\section{H3: Profitabilitas Berpengaruh positif signifikan Terhadap Nilai Perusahaan.}

\section{Pengaruh Likuiditas Terhadap Nilai Perusahaan}

Rasio likuiditas atau sering juga disebut rasio modal kerja merupakan rasio yang digunakan untuk mengukur seberapa likuidnya suatu perusahaan. Artinya apabila perusahaan ditagih, perusahaan akan mampu untuk memenuhi utang tersebut terutama utang yang sudah jatuh tempo. Dalam penelitian ini rasio likuiditas diproksikan dengan current ratio yaitu rasio yang digunakan untuk megukur kemampuan perusahaan dalam membayar kewajiban jangka pendek atau utang yang segera jatuh tempo pada saat ditagih secara keseluruhan. Semakin tinggi rasio ini berarti perusahaan semakin likuid yang pada akhirnya akan meningkatkan nilai perusahaan sehingga investor akan tertarik untuk menanamkan modalnya pada perusahaan tersebut. Signaling theory juga mejadi dasar untuk menunjukkan pengaruh likuiditas terhadap nilai perusahaan, dimana semakin likuid perusahaan akan memberikan sinyal bagi investor untuk melakukan investasi.

Berdasarkan penelitian Oktaviarni, dkk (2019) dan Lubis, dkk (2017) menyatakan bahwa likuiditas berpengaruh positif terhadap nilai perusahaan. Berdasarkan penelitian terdahulu tersebut maka hipotesis keempat adalah:

\section{H4: Likuiditas Berpengaruh Positif Terhadap Nilai Perusahaan.}

\section{METODE PENELITIAN}

\section{Populasi dan Sampel}

Populasi dalam penelitian ini adalah perusahaan-perusahaan sub-sektor Farmasi yang terdaftar di Bursa Efek Indonesia periode tahun 2016-2019 sebanyak 10 perusahaan subsektor farmasi. Sedangkan sampel perusahaan ditentukan dengan menggunakan purposive sampling yaitu teknik penentuan sampel dengan pertimbangan tertentu (Sugiyono, 2011). Beberapa kriteria yang digunakan dalam pemilihan sampel adalah 1). Perusahaan Subsektor Farmasi yang terdaftar di Bursa Efek Indonesia selama kurun waktu tahun pengamatan 2016-2019, 2). Perusahaan tersebut menyajikan laporan keuangan serta data rasio keuangan yang berkaitan dengan pengukuran variabel yang akan diteliti. Berdasarkan kriteria maka sampel penelitian adalah 9 perusahaan farmasi, hanya satu perusahaan yang tidak memenuhi kriteria yaitu Phapros Tbk karena baru listing atau IPO di BEI pada 26 Desember 2018. Sehingga unit analisis dalam penelitian ini adalah 36. 


\section{Definisi Operasional Variabel dan Pengukuran}

\section{Nilai Perusahaan}

Nilai perusahaan lazim diindikasikan dengan price to book value, yang menggambarkan seberapa besar pasar menghargai nilai buku saham suatu perusahaan. Semakin tinggi rasio ini berarti pasar percaya akan prospek perusahaan tersebut. Secara sistematis price to book value (PBV) dapat dihitung dengan rumus sebagai berikut:

$$
\mathrm{PBV}=\frac{\text { Harga Saham/Lembar Saham }}{\text { Nilai Buku/Lembar Saham }}
$$

\section{Intellectual Capital}

Intellectual capital (IC) adalah seperangkat aset tak berwujud (sumber daya, kemampuan dan kompetensi) yang menggerakkan kinerja organisasi dan penciptaan nilai. IC seingkali dirujuk sebagai selisih antara nilai pasar dan nilai buku perusahaan, dimana nilai ini dipengaruhi oleh pengembangan IC perusahaan Jadi, jika perusahaan ingin meningkatkan nilai pasar sahamnya, maka penting bagi perusahaan untuk mengelola dan mengungkapkan IC nya.

Intellectual capital dihitung berdasarkan value added yang diciptakan oleh value added capital employed (VACA), value added human capital (VAHU) dan structural capital value added (STVA). Kombinasi dari ketiga value added tersebut disimbolkan dengan nama VAICTM. Tahapan dalam perhitungan VAIC adalah sebagai berikut:

\section{Value Added (VA)}

Value added adalah indikator paling objektif untuk menilai keberhasilan bisnis dan menunjukkan kemampuan perusahaan dalam penciptaan nilai (Value Creation). Value added merupakan selisih antara output dan input. Output (OUT) merepresentasikan revenue dan mencakup seluruh produk dan jasa yang dijual di pasar, sedangkan input (IN) mencakup seluruh beban yang digunakan dalam memperoleh revenue. Hal penting dalam model ini adalah bahwa beban karyawan (labour exspenses) tidak termasuk dlam input karena itu aspek kunci dalam model pulic adalah memperlakukan tenaga kerja sebagai entitas penciptaan nilai (Ulum, 2009).

$$
V A=O U T P U T-I N P U T
$$

Keterangan:

VA = Value Added (selisih antara output dan input)

OUTPUT $=$ Total penjualan dan pendapatan lain

INPUT = Beban (bunga $\&$ operasional) dan biaya lain-lain (selain beban karyawan) 


\section{Value Added Capital Employed (VACA)}

VACA adalah adalah sebuah indikator untuk VA yang diciptakan oleh satu unit physical capital. VACA merupakan perbandingan antara value added (VA) dengan capital employed (CE). Rasio ini menunjukkan kontribusi yang dibuat oleh setiap unit dari physical capital terhadap value added organisasi. CE terdiri atas dana yang tersedia yaitu ekuitas ditambah laba bersih (Ulum, 2009).

$$
V A C A=V A / C E
$$

Keterangan :

VACA = Value Added Capital Employed

$\mathrm{VA} \quad=$ Value Added

$\mathrm{CE} \quad=$ Capital Employed yaitu dana yang tersedia (ekuitas + laba bersih)

The Human Capital Coefficient (VAHU)

VAHU menunjukkan seberapa besar VA dapat dihasilkan dengan dana yang dikeluarkan untuk tenaga kerja. Jadi hubungan antara VA dan HC mengindikasikan kemampuan $\mathrm{HC}$ membentuk nilai dalam sebuah perusahaan. Rasio ini menunjukkan kontribusi yang dibuat oleh setiap rupiah yang diinvestasikan dalam HC untuk menghasilkan nilai lebih bagi perusahaan (Ulum, 2009).

$$
V A H U=V A / H C
$$

Keterangan:

$$
\begin{array}{ll}
\text { VAHU } & =\text { Value Added Human Capital } \\
\text { VA } & =\text { Value Added } \\
\text { HC } & =\text { Human Capital (beban karyawan) }
\end{array}
$$

Beban karyawan dalam penelitian ini termasuk gaji, bonus, pelatihan, dan biaya-biaya lain yang bersangkutan dengan tenaga kerja dan tercantum dalam laporan keuangan perusahaan.

\section{Structural Capital Coefficient (STVA)}

STVA menunjukkan kontribusi modal struktural (SC) dalam pembentukan nilai. STVA yang merupakan rasio SC terhadap VA. Rasio ini mengukur jumlah SC yang dibutuhkan untuk menghasilkan 1 rupiah dari VA dan merupakan indikasi bagaimana keberhasilan SC dalam penciptaan nilai. SC merupakan VA dikurangi HC (Ulum, 2009)

$$
S T V A=S C / V A
$$


Keterangan:

STVA = Structural Capital Value Added

VA $\quad=$ Value Added

$\mathrm{SC} \quad=$ Structural Capital $(\mathrm{VA}-\mathrm{HC})$

Value Added Intellectual Coefficient (VAIC)

VAIC merupakan indikasi kemampuan intelektual sebuah perusahaan yang dianggap sebagai BPI (Business Performance Indicator). Keunggulan dari metode VAIC adalah data yang dibutuhkan relatif mudah diperoleh dari berbagai sumber. VAIC merupakan penjumlahan dari 3 komponen sebelumnya, yaitu: VACA, VAHU, dan STVA.

$V A I C^{T M}=V A C A+V A H U+S T V A$

Leverage

Rasio leverage digunakan untuk mengukur kemampuan perusahaan dalam memenuhi seluruh kewajibannya, baik kewajiban jangka pendek maupun kewajiban jangka panjang. Leverage menjadi penting bagi investor dalam membuat keputusan investasi karena dapat mempengaruhi kemampuan perusahaan untuk memberikan pengembalian kepada pemegang saham.

Rasio yang digunakan dalam penelitian ini adalah yakni Debt to Equity Ratio (DER). DER digunakan untuk melihat pengaruh pinjaman dari kreditor baik yang digunakan sebagai tambahan modal maupun sumber dana untuk pembelian aktiva. Rumus untuk mencari debt to equity ratio sebagai berikut :

$$
\text { DER }=\frac{\text { Total Utang }}{\text { Totoal Ekuitas }}
$$

\section{Profitabilitas}

Profitabilitas merupakan hasil akhir dari sejumlah kebijakan dan keputusan yang dilakukan oleh perusahaan. Dalam penelitian ini profitabilitas diukur dengan menggunakan Return On Equity (ROE). Return On Equity (ROE) merupakan alat ukur untuk mengukur kemampuan perusahaan memperoleh laba yang tersedia bagi para pemegang saham perusahaan. Rumus ROE adalah :

$$
\text { ROE }=\frac{\text { Laba Bersih }}{\text { Modal Sendiri }} \times 100 \%
$$




\section{Likuiditas}

Likuiditas adalah kemampuan suatu perusahaan untuk memenuhi kewajibannya dalam jangka pendek dengan dana lancar yang tersedia (Hayati, 2017, p. 31). Rasio likuiditas berguna untuk menganalisa seberapa jauh perusahaan mampu bertahan hidup, seberapa besar kemampuan dan kecepatan perusahaan tersebut mampu membayar hutang jangka pendeknya (kurang dari satu tahun). Rasio yang digunakan untuk mengukur likuiditas dalam penelitian ini adalah Current Rasio (CR). Semakin tinggi rasio ini, artinya perusahaan semakin baik dalam hal memenuhi kewajiban jangka pendeknya yang akhirnya akan menjadi sinyal yang baik bagi kreditor sebagai pihak penyedia dana untuk memberikan pinjaman kepada perusahaan, sedangkan investor sebagai pihak yang menanamkan modal akan tertarik untuk menanamkan modalnya pada perusahaan tersebut sehingga dengan ini diharapkan akan meningkatkan nilai perusahaan. Rumus untuk mencari CR adalah:

$$
\mathrm{CR}=\frac{\text { Total Altiva Lancar }}{\text { Total Kewajiban Lancar }} \times 100 \%
$$

\section{Metode Analisis Data}

Metode analisis data dalam penelitian ini menggunakan analisis deskriptif kuantitatif dan analisis regresi data panel untuk mengukur pengaruh variabel independen dan variabel dependen. Analisis deskriptif kuantitatif adalah pengolan data dengan metode statiska dan datanya berupa numerical atau angka. Analisis regresi data panel merupakan gabungan antara data cross section dan time series. Keunggulan dari penggunaan data panel salah satunya adalah dapat memberikan data yang lebih informative dan lebih baik dalam mendeteksi dan mengatur efek yang tidak dapat diamati dalam data time series dan cross section. Untuk pengolahan data dengan program EViews versi 9.0.

\section{HASIL PENELITIAN DAN PEMBAHASAN}

\section{Hasil Uji Statisik Deskriptif}

Analisis statistik deskriptif memberikan gambaran suatu data yang dapat dilihat dari nilai rata-rata (mean), standar deviasi, nilai maksimum dan minimum pada tabel berikut:

\section{Tabel 1}

Analisis Statistik Deskriptif

\begin{tabular}{lccccc}
\hline & PBV & IC & DER & ROE & CR \\
\hline Mean & 6.168142 & 0.085756 & 0.927065 & 0.201044 & 3.142232 \\
Median & 2.486222 & 0.267328 & 0.467879 & 0.143109 & 2.769147 \\
Maximum & 40.56250 & 12.42645 & 4.946518 & 2.244585 & 8.318226 \\
Minimum & 0.169206 & -10.34579 & 0.083299 & -0.087922 & 0.993594 \\
Std. Dev. & 9.944996 & 4.149129 & 0.984374 & 0.369741 & 1.754526 \\
\hline Observations & 36 & 36 & 36 & 36 & 36 \\
\hline
\end{tabular}

Sumber : Data Olahan, 2021 


\section{Pemilihan Model Regresi Data Panel}

Uji chow adalah pengujian untuk menentukan antara model Common Effect atau Fixed Effect yang lebih tepat digunakan dalam mengestimasi data panel. Berdasarkan Hasil Uji Chow diketahui bahwa probabilitas Chi-square adalah $0.0001<0,05$ maka dapat disimpulkan model Fixed Effect lebih baik dibandingkan dengan model Common Effect. Karena pada uji chow model yang terpilih adalah Fixed Effect maka perlu dilakukan uji lagi, yaitu uji hausman. Uji hausman dilakukan untuk mengetahui apakah model fixed effect atau model random effect yang akan digunakan dalam penelitian ini. Berdasarkan hasil uji hausman diketahui bahwa probabilitas Chi-square adalah $0.0261<0,05$ maka dapat model yang digunakan sebaiknya adalah model Fixed Effect.

\section{Hasil Uji Asumsi Klasik}

\section{Uji Normalitas}

Uji normalitas adalah untuk melihat apakah nilai residual terdistribusi normal atau tidak. Model regresi yang baik adalah memiliki nilai residual yang terdistribusi normal. Nilai residual dikatakan berdistribusi normal jika nilai residual terstandardisasi tersebut sebagian besar mendekati nilai rata-ratanya. Berdasarkan hasil uji Jarque-Bera diketahui bahwa nilai Jarque-Bera adalah sebesar 4.028557 dengan probability $0.133417>0.05$ maka dapat dikatakan bahwa data berdistribusi normal.

\section{Uji Multikolinieritas}

Uji multikolinieritas adalah untuk melihat ada atau tidaknya korelasi yang tinggi antara variable-variabel bebas dalam suatu model regresi linear berganda. Model regresi yang baik seharusnya tidak terjadi korelasi di antara variabel independent. Berdasarkan hasil uji multikolinearitas diketahui bahwa tidak ada masalah Multikolonieritas, hal ini dapat dilihat dari nilai VIF pada Centered VIF untuk ke 5 (lima) variabel independen yaitu Intellectual Capital (IC) sebesar 1.053385, Leverage (DER) sebesar 1.322533, Profitabilitas (ROE) sebesar 1.093034, dan Likuiditas (CR) sebesar $1.397012<10$ maka tidak ada masalah Multikolonieritas.

\section{Uji Heteroskedastisitas}

Uji heterokedastisitas bertujuan untuk menguji apakah dalam model regresi terdapat ketidaksamaan variance dari residual satu pengamatan ke pengamatan yang lain. Jika variance dari residual satu pengamatan ke pengamatan lain tetap, maka disebut homoskedastisitas dan jika variance tidak konstan atau berubah-ubah disebut dengan heterokedastisitas. Model regresi yang baik adalah homoskedastisitas atau tidak terjadi 
heteroskedastisitas.

Berdasarkan hasil uji heteroskedastisitas glejser diketahui bahwa nilai probability variabel independen dalam penelitian ini yaitu Intellectual Capital (IC) sebesar 0.0542, Leverage (DER) sebesar 0.5264, Profitabilitas (ROE) sebesar 0.7227, dan likuiditas (CR) adalah sebesar $0.1212>0,05$ sehingga dapat disimpulkan tidak terjadi heteroskedastisitas.

\section{Uji Autokorelasi}

Uji autokorelasi bertujuan untuk melihat apakah dalam suatu model regresi linier ada korelasi antar kesalahan pengganggu (residual) pada teriode $t$ dengan kesalahan pada periode t-1 (sebelumnya). Jika terjadi korelasi, maka dinamakan ada masalah autokorelasi. Model regresi yang baik adalah regresi yang bebas dari autokorelasi. Berdasarkan Hasil Uji Autokorelasi menunjukkan nilai $O b s^{*} R$-squared adalah 3.270453 dengan probabilitas 0.1949 $>$ 0,05 maka dapat disimpulkan bahwa tidak terjadi Autokorelasi.

\section{Hasil Regresi Data Panel}

Analisis regresi data panel pada penelitian ini menggunakan metode fixed effect. Pemilihan metode fixed effect sebagai metode analisis data panel pada penelitian ini sebelumnya diuji melalui uji chow dan uji hausman terlebih dahulu, sehingga akhirnya metode fixed effect yang paling tepat untuk menguji data panel pada penelitian ini.

\section{Hasil Uji Kelayakan Model}

\section{Tabel 2}

\section{Uji Signifikansi Simultan (Uji F)}

\begin{tabular}{llll}
\hline F-statistic & 15.40942 & Durbin-Watson stat & 2.251798 \\
\hline Prob(F-statistic) & 0.000000 &
\end{tabular}

Sumber: Data Olahan (2021)

Berdasarkan hasil pada tabel 2 diperoleh nilai $F_{\text {hitung }}$ sebesar $15.40942>F_{\text {tabel }} 2,68$ dengan probabilitas sebesar $0.000000<0,05$ maka dapat disimpulkan bahwa seluruh variabel independen secara bersama-sama berpengaruh signifikan terhadap variabel dependen. Artinya intellectual capital (IC), leverage (DER), profitabilitas (ROE) dan likuiditas (CR) secara bersama-sama berpengaruh terhadap nilai perusahaan (PBV). Dengan demikian model yang dibentuk pada penelitian ini layak untuk menginterpretasikan pengaruh variabel bebas terhadap variabel terikat.

\section{Koefisien Determinasi (Adjusted R2)}

Koefisien determinasi $\left(\mathrm{R}_{2}\right)$ atau goodness of fit merupakan nilai yang menyatakan proporsi atau persentase dari total variasi variable dependen (Y) yang dapat dijelaskan oleh 
variabel penjelas $(\mathrm{X} 1, \mathrm{X} 2, \mathrm{X} 3, \ldots, \mathrm{Xn})$ secara bersama-sama. Nilai koefisien determinasi $\left(\mathrm{R}_{2}\right)$ mengandung kelemahan mendasar di mana adanya bias terhadap jumlah variabel independen yang dimasukkan dalam model. Oleh karena itu, pada penelitian ini menggunakan nilai adjusted $R$-squared berkisar antara nol sampai satu. Apabila nilai adjusted $R$-squared makin mendekati satu, maka makin baik kemampuan model dalam menjelaskan variabel dependen.

\section{Tabel 3}

\section{Hasil Uji Koefisien Determinasi}

\begin{tabular}{llll}
\hline R-squared & 0.889377 & Mean dependent var & 3.312222 \\
\hline Adjusted R-squared & 0.831660 & S.D. dependent var & 1.803246
\end{tabular}

Sumber: Data Olahan 2021

Berdasarkan hasil tabel di atas, nilai adjusted R-squared sebesar 0.83166. Hal ini menunjukan bahwa kontribusi seluruh variabel independen dalam menjelaskan variabel dependen adalah sebesar $83.16 \%$, sedangkan sisanya sebesar $16.84 \%$ dijelaskan oleh variabel lain di luar model.

\section{Pengujian Hipotesis}

Adapun hasil uji parsial (uji t) dalam penelitian ini dapat diliat pada tabel dibawah ini, sebagai berikut:

\section{Tabel 4}

\section{Hasil Uji Regresi Data Panel Model Fixed Effect}

Dependent Variable: PBV?

Method: Pooled Least Squares

Date: 03/18/21 Time: 22:52

Sample: 20162019

Included observations: 4

Cross-sections included: 9

Total pool (balanced) observations: 36

\begin{tabular}{ccccc}
\hline Variable & Coefficient & Std. Error & t-Statistic & Prob. \\
\hline C & 1.287554 & 0.604079 & 2.131434 & 0.0440 \\
IC? & 0.202322 & 0.073999 & 2.734110 & 0.0118 \\
DER? & 0.930551 & 0.268691 & 3.463272 & 0.0021 \\
ROE? & 0.069663 & 0.020329 & 3.426701 & 0.0023 \\
CR? & 0.000533 & 0.001461 & 0.364939 & 0.7185
\end{tabular}

Fixed Effects (Cross)

Sumber: Data Olahan 2021

Berdasarkan hasil pengolahan regresi data panel dengan menggunakan model fixed effect, maka diperoleh persamaan regresi sebagai berikut:

$\mathrm{PBV}_{\mathrm{it}}=1.287554+0.202322 \mathrm{IC}_{\mathrm{it}}+0.930551 \mathrm{DER}_{\mathrm{it}}+0.069663 \mathrm{ROE}_{\mathrm{it}}+0.000533 \mathrm{CR}_{\mathrm{it}}+\mathrm{e}$ 
Keterangan:

$\begin{array}{ll}\mathrm{PBV}_{\mathrm{it}} & =\text { Price to Book Value (Nilai perusahaan) } \\ \beta_{0} & =\text { Konstanta } \\ \beta_{1}, \beta_{2}, \beta_{3}, \beta_{4}, \beta_{5} & =\text { Koefisien Regresi Variabel Independen } \\ \mathrm{IC}_{\mathrm{it}} & =\text { Intellectual Capital } \\ \mathrm{DER}_{\mathrm{it}} & =\text { Debt to Equity Ratio (Leverage) } \\ \mathrm{ROE}_{i t} & =\text { Return on Equity (Profitabilitas) } \\ \mathrm{CR}_{\mathrm{it}} & =\text { Current Ratio (Likuiditas) } \\ \mathrm{e}_{\mathrm{it}} & =\text { Error }\end{array}$

\section{Uji Signifikansi Parsial (Uji t)}

Nilai $\mathrm{t}$ tabel dapat dilihat pada tabel $\mathrm{t}$ statistik pada $\mathrm{df}=\mathrm{n}-\mathrm{k}(82-5=77)$ dengan signifikansi 0,05. Berdasarkan hasil perhitungan maka diperoleh ttabel sebesar 1,665. Berikut hasil uji t yang diperoleh dari olahan software Eviews10:

\section{Pengaruh Intellectual Capital Terhadap Nilai Perusahaan}

Hipotesis pertama yang diajukan pada penelitian ini adalah Intellectual Capital (IC) berpengaruh terhadap nilai perusahaan (PBV). Berdasarkan hasil uji parsial ( $\mathrm{t}$ ) yakni hasil pengujian parsial antara variabel intellectual capital (IC) dengan nilai perusahaan (PBV) menunjukan nilai $t_{\text {hitung }}$ sebesar $2.734110>t_{\text {tabel }}$ 2,309 dengan nilai probabilitas sebesar $0.0118<0,05$. Maka dari penelitian ini hipotesis yang diajukan diterima dan disimpulkan bahwa intellectual capital (IC) berpengaruh positif signifikan terhadap nilai perusahaan (PBV). Hasil penelitian konsisten dengan penelitian Juwita dan Angela (2016) yang menyimpulkan bahwa Intellectual Capital (IC) secara parsial memiliki pengaruh yang signifikan dan positif terhadap nilai perusahaan. Pernyataan tersebut sejalan dengan penelitian yang dilakukan oleh Santiani (2018) yang menyatakan bahwa intellectual capital secara parsial berpengaruh positif signifikan terhadap nilai perusahaan.

Salah satu keunggulan intellectual capital adalah sebagai alat untuk menentukan nilai perusahaan dan diyakini dapat meningkatkan nilai. Investor cenderung akan membayar lebih tinggi saham perusahaan yang memiliki sumber daya intelektual yang lebih tinggi daripada perusahaan lainnya. Semakin tinggi harga saham berarti semakin tinggi pula nilai perusahaan. Maka dapat disimpulkan semakin tinggi kualitas sumber daya manusia didalam perusahaan maka dapat meningkatkan kinerja operasional perusahaan. Resource based theory menjelaskan bahwa kinerja perusahaan akan optimal jika perusahaan memiliki keunggulan kompetitif sehingga bisa menghasilkan nilai bagi perusahaan. 
Meningkatnya intellectual capital juga dapat meningkatkan daya saing perusahaan di pasar saham, apabila daya saing perusahaan meningkat maka dapat menguntungkan perusahaan sehingga nilai perusahaan juga dapat meningkat bagi para investor maupun publik. Hal ini membuat para investor tertarik untuk menanamkan sahamnya di perusahaan tersebut karena dengan meningkatnya nilai perusahaan maka dapat menjadikan sinyal positif bagi para investor untuk menanamkan sahamnya di perusahaan tersebut. Hasil penelitian membuktikan bahwa tingginya Intellectual Capital membuat nilai perusahaan (PBV) juga menjadi meningkat signifikan.

\section{Pengaruh Leverage Terhadap Nilai Perusahaan}

Hipotesis kedua yang diajukan pada penelitian ini adalah Leverage berpengaruh positif terhadap Nilai Perusahaan (PBV). Berdasarkan hasil uji parsial (t) yakni hasil pengujian parsial antara variabel Leverage (DER) dengan nilai perusahaan (PBV) menunjukan nilai $\mathrm{t}_{\text {hitung }}$ sebesar $3.463272>\mathrm{t}_{\text {tabel }}$ 2,309 dengan nilai probabilitas sebesar $0.0021<0,05$. Maka pada penelitian ini hipotesis yang diajukan diterima dan disimpulkan bahwa Leverage berpengaruh positif signifikan terhadap nilai perusahaan (PBV).

Hasil penelitian konsisten dengan penelitian yang dilakukan oleh Suffah dan Riduwan (2016), menyatakan bahwa leverage berpengaruh positif signifikan terhadap nilai perusahaan. Pernyataan tersebut juga didukung oleh beberapa penelitian yaitu Pratama dan Wiksuana (2016) Sari dan Handayani (2016) yang menyatakan bahwa leverage berpengaruh positif signifikan terhadap nilai perusahaan.

Leverage perlu dikelola karena penggunaan hutang yang tinggi akan meningkatkan nilai perusahaan. Peningkatan hutang dipandang positif oleh investor sebagai meningkatnya kesempatan perusahaan untuk berkembang sehingga investor berkesempatan untuk mendapatkan pengembalian investasi yang lebih tinggi tanpa harus mengurangi proporsi kepemilikan investor terhadap perusahaan. Hal ini berarti perusahaan yang berhutang mempunyai nilai perusahaan yang tinggi. Hasil penelitian membuktikan bahwa semakin tinggi tingkat leverage maka semakin meningkat pula nilai perusahaan.

\section{Pengaruh Profitabilitas Terhadap Nilai Perusahaan}

Hipotesis ketiga yang diajukan pada penelitian ini adalah Profitabilitas berpengaruh positif signifikan terhadap nilai perusahaan (PBV). Berdasarkan hasil uji parsial (t) yakni hasil pengujian parsial antara variabel profitabilitas (ROE) dengan nilai perusahaan (PBV) menunjukan nilai $t_{\text {hitung }}$ sebesar $3.426701>t_{\text {tabel }}$ 2,309 dengan nilai probabilitas sebesar $0.0023<0,05$. Maka pada penelitian ini hipotesis yang diajukan diterima dan dapat 
disimpulkan bahwa Profitabilitas berpengaruh positif signifikan terhadap nilai perusahaan (PBV).

Hasil penelitian ini konsisten dengan penelitian yang dilakukan oleh Oktaviarni, dkk (2019), menyatakan bahwa Profitabilitas (ROE) berpengaruh positif terhadap nilai perusahaan. Pernyataan tersebut juga didukung oleh beberapa penelitian seperti Novari dan Lestari (2016) dan Dewi, dkk (2017) serta Lubis, dkk (2017) yang menyatakan bahwa profitabilitas (ROE) berpengaruh positif signifikan terhadap nilai perusahaan.

Profitabilitas berpengaruh terhadap nilai perusahaan karena dapat dikatakan apabila laba yang dihasilkan perusahaan ini meningkat maka dapat meningkatkan harga saham di perusahaan, dengan meningkatnya harga saham ini menjadikan daya tarik bagi investor untuk menanamkan sahamnya di perusahaan tersebut. Semakin tinggi minat investor menanamkan sahamnya pada perusahaan yang memiliki aset yang besar maka dapat meningkatkan harga saham pada perusahaan sehingga semakin meningkat harga saham pada perusahaan tersebut. Hal ini dapat menjadikan adanya hubungan positif antara harga saham dengan profitabilitas, karena semakin tinggi harga saham maka akan mempengaruhi nilai perusahaan karena nilai perusahaan tercermin dari harga sahamnya.

\section{Pengaruh Likuiditas Terhadap Nilai Perusahaan}

Hipotesis keempat yang diajukan pada penelitian ini adalah likuiditas berpengaruh positif terhadap nilai perusahaan (PBV). Berdasarkan hasil uji parsial ( $\mathrm{t}$ ) yakni hasil pengujian parsial antara variabel likuiditas (CR) dengan nilai perusahaan (PBV) menunjukan nilai thitung sebesar $0.364939<t_{\text {tabel }} 2,309$ dengan nilai probabilitas sebesar $0.7185>0,05$. Maka pada penelitian ini hipotesis yang diajukan ditolak dan dapat disimpulkan bahwa likuiditas tidak berpengaruh terhadap nilai perusahaan (PBV).

Likuiditas merupakan kemampuan suatu perusahaan memenuhi kewajiban keuangannya dalam jangka pendek, atau yang harus segera dibayar. Hasil penelitian ini menunjukkan bahwa, likuiditas tidak berpengaruh terhadap nilai perusahaan. Hasil penelitian ini sejalan dengan penelitian yang dilakukan oleh Nurhayati (2013) yang menyatakan bahwa likuiditas tidak berpengaruh terhadap nilai perusahaan. Kondisi Ini menyatakan bahwa seorang investor dalam melakukan investasi tidak memperhatikan faktor likuiditas yang diproksikan dengan current ratio yang dimiliki oleh perusahaan. Likuiditas dalam suatu perusahaan hanya menunjukkan kemampuan perusahaan dalam memenuhi kewajiban jangka pendeknya sehingga likuiditas tidak berpengaruh dalam pertumbuhan nilai perusahaan. Seorang investor kurang tertarik pada rasio likuiditas karena menyangkut tentang kondisi 
internal suatu perusahaan dalam memenuhi kewajiban jangka pendeknya, tetapi investor lebih mempehatikan rasio jangka panjang yang lebih memiliki nilai atas pengembalian investasinya. Selain itu seorang investor tidak memperdulikan besar atau kecilnya current ratio, karena fokus para investor adalah pada kemampuan perusahaan dalam menghasilkan laba. Seperti diketahui nilai perusahaan bukan didasarkan pada kemampuan perusahaan dalam melunasi hutangnya tetapi kemampuan perusahaan dalam mengelola aset, modal sendiri, dan penjualan untuk menghasilkan laba yang mencerminkan nilai perusahaan yang diukur dari harga sahamnya. Kondisi ini yang menyebabkan likuiditas tidak berpengaruh terhadap nilai perusahaan.

\section{SIMPULAN}

Berdasarkan hasil penelitian yang telah dilakukan, setelah melalui tahap pengumpulan data, pengolahan data, analisis regresi data panel dan menginterpretasi hasil analisis mengenai pengaruh intellectual capital, leverage, profitabilitas dan likuiditas terhadap nilai perusahaan pada perusahaan sub-sektor farmasi yang listing di BEI Periode 2016-2019, maka dapat disimpulkan sebagai berikut variabel intellectual capital berpengaruh positif signifikan terhadap nilai perusahaan. Investor cenderung akan membayar lebih tinggi harga saham bagi perusahaan yang memiliki sumber daya intelektual yang lebih tinggi daripada perusahaan lainnya. Semakin tinggi harga saham berarti semakin tinggi pula nilai perusahaan. Variabel leverage berpengaruh positif signifikan terhadap nilai perusahaan. Penggunaan hutang yang tinggi akan meningkatkan nilai perusahaan karena peningkatan hutang dipandang positif oleh investor sebagai meningkatnya kesempatan perusahaan untuk berkembang.

Variabel profitabilitas berpengaruh positif signifikan terhadap nilai perusahaan. Semakin tinggi profitabilitas perusahaan akan meningkatkan laba per lembar saham perusahaan. Adanya peningkatan laba per lembar saham perusahaan akan membuat investor tertarik untuk menanamkan modalnya dengan membeli saham perusahaan. Dengan banyaknya investor yang membeli saham perusahaan maka akan menaikkan harga saham perusahaan tersebut sehingga akan meningkatkan nilai perusahaan.

Variabel likuiditas tidak berpengaruh signifikan terhadap nilai perusahaan. Likuiditas dalam suatu perusahaan hanya menunjukkan kemampuan perusahaan dalam memenuhi kewajiban jangka pendeknya. Seorang investor kurang tertarik pada rasio likuiditas karena menyangkut tentang kondisi internal suatu perusahaan dalam memenuhi kewajiban jangka pendeknya, sebab investor lebih memperhatikan rasio jangka panjang yang lebih memiliki nilai atas pengembalian investasinya. 
Keterbatasan dalam penelitian ini adalah jumlah sampel perusahaan yang terbatas dan periode penelitian yang singkat sehingga diharapakn penelitian selanjutnya dapat menambah sampel perusahaan yang mencakup semua jenis perusahaan yang terdaftar di Bursa Efek Indonesia. Selain itu, disarankan kepada peneliti selanjutnya untuk memperluas variabel keuangan lainnya yang memiliki pengaruh lebih besar terhadap nilai perusahaan.

\section{REFERENSI}

Chandra, H., \& Djadjadikerta, H. (2017). Pengaruh Intellectual Capital, Profitabilitas, dan Leverage Terhadap Nilai Perusahaan Pada Perusahaan Sektor Properti, Real Estate, Dan Kontruksi Bangunan Yang Terdaftar di Bursa Efek Indonesia. Ultima Accounting

Dewi, A.A K., Badjra, I. B. (2017). Pengaruh Profitabilitas, Aktiva Tidak Berwujud, Ukuran Perusahaan, Dan Struktur Modal Terhadap Nilai Perusahaan. E-Jurnal Manajemen Unud, Vol. 6, No. 4, 2161-2190.

Faza, Muhammad, F., \& Hidayah, E. (2014). Pengaruh Intellectual Capital Terhadap Profitabilitas, Produktivitas, Dan Nilai Perusahaan Pada Perusahaan Perbankan Yang Terdaftar Di Bursa Efek Indonesia. EKBISI, Vol. VIII, No. 2, hal. 186-199. Universitas Islam Indonesia

Febriana, E., Djumahir., \& Djawahir, A.H. (2016). Pengaruh Struktur Modal, Kebijakan Dividen, Ukuran Perusahaan, Kepemilikan Saham Manajerial dan Profitabilitas Terhadap Nilai Perusahaan (Studi pada Perusahaan Manufaktur yang Terdaftar di BEI Pada 2011-2013), Jurnal Ekonomi Bisnis Tahun 21, Nomor 2.

Hanafi, M. M. (2016). Manajemen Keuangan (Revisi). BPFE.

Hayati, S. (2017). Manajemen Aset dan Liabilitas. Penerbit Andi.

Juwita, R., \& Angela, A (2016). Pengaruh Intellectual Capital Terhadap Nilai Perusahaan Pada Perusahaan Indeks Kompas 100 Di Bursa Efek Indonesia. Jurnal Akuntansi Maranatha, vol. 8, no. 1, pp. 1-15.

Khumairoh, N. K., \& Mulyati, H. (2016). Pengaruh Leverage, Profitabilitas, dan Ukuran Perusahaan Terhadap Nilai Perusahaan, Syariah Paper Accounting FEB UMS, hal. 7181.

Lubis, I. L., Sinaga, B. M., Sasangko, H. (2017). Pengaruh Profitabilitas, Sruktur Modal, Dan Likuiditas Terhadap Nilai Perusahaan. Jurnal Aplikasi Bisnis dan Manajemen, Vol. 3 No. 3, 458-465.

Moniaga, F. (2013). Struktur Modal, Profitabilitas dan Struktur Biaya Terhadap Nilai Perusahaan Industri Keramik, Porcelen Dan Kaca Periode 2007 - 2011. Jurnal EMBA Vol.1 No.4, hal. 433-442.

Novari, P., \& Lestari, P. (2016). Pengaruh Ukuran Perusahaan, Leverage, Dan Profitabilitas Terhadap Nilai Perusahaan Pada Sektor Properti Dan Real Estate. E-Jurnal Manajemen Unud, Vol. 5, No.9, 5671-5694. 
Nurhayati, M. (2013). Profitabilitas, Likuiditas, dan Ukuran Perusahaan Pengaruhnya Terhadap Kebijakan Dividen dan Nilai Perusahaan Sektor Non Jasa. Jurnal Keuangan dan Bisnis.5(2),144-153

Nurminda. A. (2017). Pengaruh Profibilitas, Leverage, dan Ukuran Perusahaan Terhadap Nilai Perusahaan. e-Proceeding of Management. Vol. 4. No. 1

Oktaviarni, F., Murni, Y., \& Suprayitno, B. (2019). Pengaruh Profitabilitas, Likuiditas, Leverage, Kebijakan Dividen, Dan Ukuran Terhadap Nilai Perusahaan. Jurnal Akuntansi Vol. 9 No. 1, 1-16.

Prastika, N. G., \& Ayu P.T S. (2012). Pengaruh Ios, Leverage dan Dividend Yield terhadap Profitabilitas dan Nilai Perusahaan Sektor Manufaktur di BEI. Jurnal Magister Manajemen Universitas Udayana: 147-174.

Pratama, I., \& Wiksuana, I. (2016). Pengaruh Ukuran Perusahaan dan Leverage Terhadap Nilai Perusahaan dengan Profitabilitas sebagai Variabel Mediasi. E-Jurnal Manajemen, 5(2).

Santiani, N. P . (2018). Pengaruh Intellectual Capital Dan Struktur Modal Terhadap Nilai Perusahaan. Jurnal Akuntansi Volume 13 Nomor 2, 69-78

Sari , A., Putri, R. M., \& Handayani, N. (2016). Pengaruh Profitabilitas, Ukuran Perusahaan dan Leverage Terhadap Nilai Perusahaan Transportasi. Jurnal Ilmu dan Riset Akuntansi. Vol 5. No 9. ISSN : 2460-0585.

Sugiyono. (2016). Metode Penelitian Kuantitatif, Kualitatif dan R\&D. PT Alfabet.

Suffah, R., \& Riduwan, A. (2016). Pengaruh Profitabilitas, Leverage, Ukuran perusahaan dan Kebijakan dividen pada Nilai perusahaan. Jurnal ilmu dan riset akuntansi. Vol.5, No.2

Ulum, I. (2009). Intellectual Capital: Konsep dan Kajian Empiris. Graha Ilmu.

Ulum, I. (2013). Model Pengukuran Kinerja Intellectual Capital Dengan Ib-Vaic Di Perbankan Syariah. Inferensi, 185-206

CNBC Indonesia, Jakarta, 02 Maret 2020 